\title{
Therapeutic play in preparing for surgery: behavior of preschool children during the perioperative period*
}

\author{
BRINQUEDO TERAPÊUTICO NO PREPARO PARA A CIRURGIA: COMPORTAMENTOS \\ DE PRÉ-ESCOLARES NO PERÍODO TRANSOPERATÓRIO
}

\author{
EL JUEGO TERAPÉUTICO EN LA PREPARACIÓN PARA LA CIRUGÍA: EL \\ COMPORTAMIENTO DE LOS PREESCOLARES DURANTE LA CIRUGÍA
}

\section{Camila Moreira Paladino', Rachel de Carvalho², Fabiane de Amorim Almeida ${ }^{3}$}

\begin{abstract}
Objective: to describe the behavior of children during the instructional session of therapeutic play (ITP) in the preoperative period and to verify the behavior presented by them during the perioperative period. Methods: Exploratory descriptive study with a quantitative approach, developed in a large private hospital in Sao Paulo, in which the behaviors presented by 30 children between three and five years old, undergoing minor surgery were seen at the hospital during the session of TP and in the surgical center, from admission to awaken from anesthesia. Results: Most children participated in the ITP session $(21 ; 70 \%)$, entered the surgical room spontaneously $(22 ; 73.3 \%)$ without resisting mother separation (24; $80 \%)$, collaborating with the anesthetic procedure $(16 ; 53.3 \%)$ and quietly awakening from anesthesia $(26 ; 87 \%)$. Conclusion: The use of ITP led the child to understand the surgical procedure, making it less traumatic.
\end{abstract}

\author{
DESCRIPTORS \\ Play and playthings \\ Child, hospitalized \\ Perioperative nursing \\ Humanization of assistance \\ Pediatric nursing
}

\begin{abstract}
RESUMO
Objetivo: Descrever o comportamento de crianças durante a sessão de brinquedo terapêutico instrucional (BTI) no período pré-operatório e verificar o comportamento apresentado por elas no período transoperatório. Método: Pesquisa descritiva exploratória de abordagem quantitativa, desenvolvida em um hospital particular de grande porte da cidade de São Paulo, na qual os comportamentos apresentados por 30 crianças entre três e cinco anos submetidas à cirurgia de pequeno porte foram observados na unidade de internação durante a sessão de BT e na sala de cirurgia, desde a admissão até despertarem da anestesia. Resultados: A maioria participou efetivamente da sessão de BTI (21; $70 \%)$, entrou espontaneamente na sala operatória $(22 ; 73,3 \%)$ e sem resistir à separação da mãe $(24 ; 80 \%)$, colaborando com o procedimento anestésico $(16 ; 53,3 \%)$ e despertando da anestesia tranquilamente (26; $87 \%$ ). Conclusão: $\mathrm{O}$ uso do BTI propiciou à criança compreender o procedimento cirúrgico, tornando-o menos traumático.
\end{abstract}

\author{
DESCRITORES \\ Jogos e brinquedos \\ Criança hospitalizada \\ Enfermagem perioperatória \\ Humanização da assistência \\ Enfermagem pediátrica
}

\begin{abstract}
RESUMEN
Objetivo: Describir el comportamiento de los niños durante una sesión de juego terapéutico instruccional en el periodo preoperatorio y verificar el comportamiento mostrado en el periodo intraoperatorio. Método: Estudio descriptivo, exploratorio, de abordaje cuantitativo, desarrollado en un hospital privado en la ciudad de São Paulo. Se observaron los comportamientos de 30 niños entre los 3 y los 5 años sometidos a cirugías menores durante la sesión de juego instruccional realizada en la unidad de internación y en el quirófano, desde su admisión en el hospital hasta el despertar de la anestesia. Resultados: La mayoría de los niños participaron efectivamente de la sesión de juego terapéutico instruccional (21; $70 \%)$, el $73 \%$ entró espontáneamente en el quirófano, el $80 \%$ no se resistió a la separación de la madre, el 53,3\% colaboró con el procedimiento anestésico y el $87 \%$ despertó tranquilamente de la anestesia. Conclusión: El uso del juego terapéutico instruccional ayudó a los niños a entender el procedimiento quirúrgico, haciéndolo menos traumático.
\end{abstract}

\footnotetext{
* Extracted from the graduation final paper "Benefícios do brinquedo terapêutico no período perioperatório" Certified Specialization in Surgical Center, Anesthetic Recovery and Material and Sterilization Center, School of Nursing, Albert Einstein Jewish Hospital, 2010. ${ }^{1}$ Nurse, Anesthesia Recovery Unit, Albert Einstein Jewish Hospital, Sao Paulo, SP, Brazil. ${ }^{2}$ PhD in Nursing, Coordinator of the Certified Specialization Course on Surgical Center, Anesthetic Recovery and Material and Sterilization Center, School of Nursing, Albert Einstein Jewish Hospital, Sao Paulo, SP, Brazil. ${ }^{3}$ PhD, Coordinator of the Certified Specialization Course in Pediatric and Neonatal Nursing, School of Nursing, Albert Einstein Jewish Hospital, Sao Paulo, SP, Brazil. fabiane.almeida@einstein.br
} 


\section{INTRODUCTION}

Surgery can be a very traumatic experience for the child, who has limited cognitive resources to understand what happens with herself/himself and deal with situations that cause stress ${ }^{(1)}$. The need to be hospitalized makes this an even more delicate moment, keeping her/ him away from the safe environment of her/his home. In contact with the unknown and frightening hospital environment, the child has to undergo a different routine, which includes several invasive and painful procedures ${ }^{(1-2)}$.

The anxiety from separation, loss of control and fear of bodily injury and pain are some of the negative effects of illness and hospitalization that affect child development, especially in the first years of life, when the child is most vulnerable to these events. Giving her/him the opportunity to play is one of the strategies that may mitigate the negative effects of this experience ${ }^{(1,3)}$.

Playing is the most important activity of a child's life. In addition to promoting child development in all its dimensions, it is the most genuine way they use to communicate and express feelings, anxieties and frustrations, which otherwise would not be possible, due to their emotional immaturity ${ }^{(4-5)}$.

Recognized as a basic need for childhood, playing is advocated by the Declaration of the Rights of the Child United Nations ${ }^{(6)} 1959$, which includes playing along with other basic needs such as food, shelter, medical care, education and parental love, and by the Statute of Children and Adolescents ${ }^{(7)}$, which considers playing children's right.

At the hospital, playing may be performed in different ways. Recreational play includes activities in which children engage spontaneously just for pleasure, being the playroom a conducive environment to develop $i t^{(4-5)}$. The role of this physical space in promoting play in the hospital provides to the adult a rich access to the seriously ill children experience ${ }^{(8)}$.

Therapeutic play, in turn, encompasses specialized activities and directed by professionals to promote physical and emotional well-being to the child in order to experience a situation of unusual life for their age, such as hospitalization and surgery ${ }^{(4-5)}$.

Among therapeutic play, we highlight the therapeutic toy (TT). This is a non-directive play, which gives the child freedom to express themselves non-verbally and without concern that the adults around them will identify when they are talking about themselves ${ }^{(4-5)}$. Suitable for any child who experiences a crisis situation, the TT can be developed by different professionals and anywhere, and the sessions last about 15 to 45 minutes $^{(4-5)}$.

In recent years, research on TT have become more frequent ${ }^{(9)}$, especially those that address the child's experience on critical and invasive procedures, in various contexts, not just in the hospital, but also at other levels of health care ${ }^{(10-12)}$.

The TT can be widely used by nurses as a best practice and regulated by the Federal Board of Nursing ${ }^{(13)}$. It is an important tool to better understand and diagnose child's needs, providing subsidies for professional nursing care plan ${ }^{(11)}$.

Studies on the perception of nurses regarding the use of TT showed that they are aware of the benefits of their practice $^{(14)}$. These studies, however, point out to the need to prepare professional to do it and incorporate it into their daily lives ${ }^{(15)}$, emphasizing that teaching about the toy and integrating it with care are still challenges to be overcome ${ }^{(16)}$.

There are different types of TT, depending on the purpose for which it is employed, and instructional and therapeutic play (ITP) is one of them. This play allows the child to learn about a particular event, such as surgery or other hospital procedures, which the understanding would be impossible with only verbal explanation. It also enables children to understand how to act and how they will feel in real time, facilitating the expression of feelings and clarifying misconceptions ${ }^{(4-5)}$.

Its routine use in units that care for children is justified by the fact that information should be clear about the need for hospitalization and surgery, which helps to alleviate anxiety, making them feel safe and able to trust the adult who cares for them. Parents and professionals find it difficult to convey this information, often omitting the truth in an attempt to save the child and not causing them suffering. When this happens, the child's trust in adults who care for them can be terribly shaken, leading them to believe that they are no longer loved.

Given these findings and considering the experience of the authors in childcare who undergo surgery, this study aimed to explore the use of ITP in preparation for surgery and its influence on child behavior in these events.

The aim of this study was to describe the behavior of preschool children undergoing minor surgery during an instructional session of therapeutic play (ITP) in the preoperative period, and after the session of ITP, in the perioperative period.

\section{METHOD}

This is a descriptive and exploratory research, conducted in the pediatric inpatient units (IU), Day Clinic and Surgical Center (SC) of an extra sized private hospital, located in the city of Sao Paulo.

The sample consisted of 30 children between three and five years old, undergoing elective minor surgery during the 2nd semester of 2010. They were intentionally selected by choosing the first 30 children who presented good general condition, who agreed to participate in the research and
Therapeutic play in preparing for surgery: behavior of preschool children during the perioperative period Paladino CM, Carvalho R, Almeida FA 
whose guardians authorized their participation by signing the Consent Form.

Data were collected by the first researcher of the study, who even though worked as a nurse in the SC unit, she did not participate in the perioperative procedures performed with the child. Data collection was performed through observation of the behavior manifested by children in two moments: ITP session held before surgery at surgery unit, and in the perioperative period from admission to the SC awakening from anesthesia.

For data records, we used an instrument developed by the researchers that was based on her experiences in surgical child care, consisting of: data on the child, her/his past history, clinical prognosis, surgery and anesthesia proposal, obtained from medical records before ITP session, so that, the researcher could plan it in advance; behavior and reactions presented by the child on admission to the SC during anesthetic induction and in the unity of post-anesthesia recovery in the form of a checklist.

To record the child's behavior in the ITP session, we used another instrument, proposed by Almeida ${ }^{(17)}$, containing two columns: the first for the full transcription of the session soon after its completion, and the second to record the behaviors identified from the careful reading of the transcription of the session.

Data collection began only after the approval of the research project by the Research Ethics Committee of the Albert Einstein Hospital (CAAE 0091.0.028.000-10) and authorization of managers of units where the data were collected.

After explaining to guardians and the child about research and if they agreed to participate, they were invited to play by choosing the location of her/his choice to perform the play. Parents or caregivers were always invited to join her/him. In ITP sessions, which lasted between 20 and 30 minutes, the researcher told the story of a child who was having a surgery, considering the details of the surgery and type of anesthesia that she/he would be subjected to. As the researcher told the story, she would dramatize the procedures with toys and in the end she would ask the child to repeat the play.

The toys were selected as recommended in the literature ${ }^{(4-5)}$ including: dolls representing the surgical team, the child and their parents; materials and medical instruments such as caps, masks, aprons, syringes and serum catheter, among others; toys related to everyday household as pans, games, ball, paper and crayons.

Data were analyzed quantitatively by means of descriptive statistics and the results were presented in absolute and relative numbers.

\section{RESULTS}

Most children were male $(20 ; 66.7 \%)$ with predominant age of three years $(13 ; 43.3 \%)$. The tonsillectomy surgery was performed more frequently $(09 ; 30 \%)$, followed by circumcision $(07 ; 23.3 \%)$ and orthopedic surgeries $(05 ; 16.7 \%)$. General anesthesia was used in the majority $(22 ; 73.3 \%)$, whereas only eight $(26.6 \%)$ received some type of lock (penile, sacral or epidural) associated with general anesthesia.

\section{Behavior of the children during the session of ITP}

Most children took part in the play effectively $(21 ; 70 \%)$, interrupting the story and asking questions (12; 40\%), becoming interested in playing again with toys at the end of the story and calling their mother/father to participate $(05$; $17 \%)$. In that moment, assimilated information were reproduced in session $(14 ; 47 \%)$, dealing with hospital toys easily $(11 ; 37 \%)$. Some children $(09 ; 30 \%)$ would ask us if they could carry with them some of the toys used during the session.

Behaviors showing a decreased involvement of children in the play were less frequent such as: no participation in the play, limiting themselves by only observing the researcher $(06 ; 20 \%)$ and concentrate on little activity due to pain or discomfort $(03 ; 10 \%)$.

\section{Behavior of children during the perioperative period}

On admission to the SC, the majority $(22 ; 73.3 \%)$ participated spontaneously, transported on stretchers. Behaviors indicating less cooperation were less frequent at this time such as the resistance of the separation from their mother (06; 20\%), crying $(04 ; 13 \%)$ and screaming $(04 ; 7 \%)$.

Upon entering the operating room, most children remained quiet $(26 ; 87 \%)$, collaborating with the anesthetist by holding the inhalation mask (16;53\%) and falling asleep quickly after anesthetic induction ( $22 ; 74 \%)$. Just some children cried $(06,20 \%)$ or became agitated during anesthetic induction (12; 4\%), needing to be contained. Two children recognized the researcher who previously played with her, commenting with other professionals on the ITP session (02; 7\%). After surgery, the majority of children woke up from the anesthesia quietly $(26 ; 87 \%)$.

\section{DISCUSSION}

Initially analyzing the behaviors presented by the children in ITP session before surgery, it appears that the children showed great interest in the play, participating actively by asking questions and repeating the play by dealing with hospital toys resourcefully.

These behaviors show that, when they play, the child is free to create and when they create, accomplish something, they express their being and are able to find themselves at that moment. Playing is always a creative and intensely real experience for the child ${ }^{(18)}$. In times when they play freely, as when they interrupt and ask or repeat the play, she/he takes the initiative, dominating the situation, and her/his ego becomes strengthened ${ }^{(19)}$. 
A study conducted with preschool children prepared with ITP before outpatient chemotherapy showed that during the session, they also showed a very similar behavior to those found in this study. They would carefully observe the dramatization of the procedures by professional and ask questions, collaborating with the professional, catering to their requests in the dramatization, and took the initiative in the play. They would also verbalize what they felt when they were undergoing the procedure in a real situation ${ }^{(20)}$.

Another study conducted with children prepared with ITP prior to cardiac surgery also pointed out that almost all children showed interest in playing before and after surgery. Only one struggled to play after surgery. Quite weakened by prolonged ICU stay due to postoperative complications, she seemed to have lost confidence in the environment, failing to play freely ${ }^{(19)}$.

It was also found that children expressed the desire to carry some of the hospital toys used in play. This finding was also found in the aforementioned study ${ }^{(19)}$. The intention of repeating a play that gave her/him great satisfaction, not only during the session, but at any time, may be related. It is emphasized that the repetition of a stressful event playfully brings stress relief, evidencing the therapeutic value of play in childhood. Asking to stay with the hospital toy after the session is a way for the child to carry part of something that brings her/him pleasure $^{(17)}$ and even the guarantee that other meetings will happen, in case she/he commits to return it later.

Although with less frequency, some behaviors showed that some children were not motivated during the play, who would only observe the researcher dramatizing the procedures, having difficulty concentrating or refusing to participate. The ability to focus is crucial if the child can play and for this, she/he must rely on the environment and people around her/him. However, the ability to trust others varies greatly from one child to another, depending on confidence experiences that each one has lived since birth ${ }^{(18)}$.

A study conducted with children from 4 to 12 years old, who underwent palate cleft lip repair, previously prepared with ITP, pointed out that the interest in handling toys increases when the child is more familiar with the situation ${ }^{(21)}$. The preparation took place in two stages: the day before surgery, when the preoperative orientations were made to the children and their family, and in the surgery day, while waiting to be sent to pre-anesthesia care unit. They had contact with the same toys and playful scenario in both situations, with a greater number of children handled the toys in the second time, when they knew the material(21).

In the perioperative period, most children in this study proved to be calm, coming spontaneously to the SC, not resisting the separation from their mother and collaborating during anesthesia, sleeping quickly.
The scientific evidence indicates that the previous preparation of the child with toys contributes significantly to the dominance indicative of acceptance and adaptation to the situation of child behaviors, as seen in this study. In a study conducted with children prepared with ITP prior to the post-surgical dressing, these behaviors have become more frequent, compared with those who received no preparation with the toy previously ${ }^{(22)}$. Among these behaviors, we highlight the interest in playing, spontaneously helping the professional and asking questions, which were also observed in this study.

Some children reported on the ITP session when they were in SC, when they realize the similarity between the actual situation and dramatization in the play, recognizing the researcher who played with them and that was present in the operating room. The child begins to trust people who play with her.

Although it is considered that the preparation with ITP positively influence the child's behavior in the face of traumatic situations, other factors have also contribute to make it happen. The persistence of a significant person close to the child makes the surgical environment less frightening, allowing the child to feel safe.

At the institution where data were collected, the mother or another caregiver accompanies the child to the operating room, often lying on bed with them. At the end of the surgical procedure, that person is already waiting for her/him in the anesthetic recovery unit, remaining near the child until discharge.

Parental separation seems to be the event that generates more stress for the child, as they represent their safe haven $^{(1)}$. Moreover, due to the magical thinking characteristic of this stage of development, they can understand surgery and hospitalization as a punishment for not behaving well or because their parents do not love them anymore ${ }^{(4-5)}$.

Another factor that contributes so that the moment of surgery is less stressful for the child and her/his family is the use of pre-anesthetic medication, routine practice in the institution where the research data were collected. This approach is effective in alleviating anxiety while promoting sedation of the child and facilitates the separation of families and the onset of anesthesia, without interfering in the time of post-anesthetic recovery ${ }^{(23)}$.

There were, however, some children who resisted the separation from their mother, crying or screaming from the entrance in SC, having to be restrained during anesthetic induction. These behaviors, characterized by lower acceptance and adaptation procedures, are expected from the hospitalized child, especially before they reach five years of life even when they have been previously prepared with the toy ${ }^{(1-2)}$.

After surgery, most children awoke quietly, once again reinforcing the findings of the study cited above ${ }^{(22)}$ which
Therapeutic play in preparing for surgery: behavior of preschool children during the perioperative period Paladino CM, Carvalho R, Almeida FA 
also identified more frequently behaviors indicative of greater acceptance and adaptation of children in conducting post-surgical dressing after preparation with ITP.

Newly admitted preschool children in an inpatient facility began to better interact with the environment and adults after attending a session of TP, which dramatized domestic and hospital situations, expressing feelings of anger and love. Before the session, they did not play, interacting very little with the environment and responding to some stimuli and requests. These findings confirm that the TP helps children to better understand what is happening, coming to realize hospitalization as less aggressive and collaborating more with the procedures ${ }^{(24)}$.

A literature review of 22 studies published between 2005 and 2011 also emphasizes that the child contributes more during procedures after preparation with ITP. By giving them the opportunity to externalize their feelings against threatening situations, the toy promotes stress relief, evidencing as an essential instrument of care in pediatrics ${ }^{(12)}$.

The play, by itself, has a relaxing potential, which is very useful in the hospitalization and healing, it reduces stress, anxiety and pain, normalizes vital signs, besides that, the process favors the bond of trust with staff because it facilitates communication and promotes entertainment, among other benefits ${ }^{(25)}$.

A study aiming to identify the benefits of the TP for the child by the nursing staff of the pediatric unit also emphasizes its value in improving the communication and strengthen the bond between children and professionals, it also enables them to verbalize their feelings. Professionals observe a more positive response from the child about the procedure and the team itself, as well as significant improvement in both emotional and clinical aspects. Also emphasizing that the family comes to trust the team ${ }^{(26)}$.

During data collection, it was observed that some parents feared that the child was afraid to hear about the surgical procedure in the ITP session. However, they are reassured when they see how the child showed increasingly interested in the story and the dramatization with toys.

A research was developed with parents and caregivers of children undergoing outpatient venipuncture in order to understand their perception regarding the use of ITP in preparation for the procedure ${ }^{(27)}$. The results showed that they are favorable to the strategy because they believe it reduces fear, calms the child and promotes the safety of both. According to them, there is no need to restrict it because usually the child is more collaborative, causing a puncture be performed more easily, increasing the chances of success in the first attempt and in less time ${ }^{(27)}$.

Concerned with not hiding the truth from the child, the family of one of them had already talked to her about the surgery using the toy. Upon entering this girl's room, who would undergo an orthopedic surgery, the researcher found a doll dressed in apron, cap, slippers, identification bracelet and a bandaged arms the same in which the child would have in surgery. It was made by the child's grandmother, who had performed a surgical procedure and realized the importance of preparing her granddaughter to cope with that.

It is important that parents are involved in the preparation of the child, because it will validate the information received with them, which are their source of security. Therefore, they should be encouraged to participate in the ITP session, they also benefit from the information transmitted during the play, clarifying the doubts that they had no courage to ask the professionals.

The results of this study contribute to reinforce the importance of the routine use of ITP in preparing children for hospital procedures. However, further research is needed to prove the effectiveness of this practice in the situation studied.

The development of experimental studies, with larger samples, comparing the use of ITP in the preparation of children in these same conditions with situations in which the ITP is not usually applied may help clarify whether this practice contributes significantly to the prevalence of behaviors of adaptation in the perioperative period or if these results come from concomitant adoption of other humanized strategies.

\section{CONCLUSION}

Preparation for surgery with ITP proved to be a pleasurable experience in itself for most children, who attended the session effectively, interrupting the play to make questions, interested in repeating the play after hearing the story that was told by the researcher and reproducing the information assimilated during preparation. In the SC, most of them spontaneously entered the operating room, keeping calm in the operating room, collaborating in anesthetic procedure and awakening calmly after surgery.

The reduced or absent number of behaviors that show fear and stress among children, such as crying, being agitated, struggling or screaming, enhances the beneficial effects of ITP in preparing the child for the surgical procedure. However, we must consider adopting other strategies that also contribute to alleviate fear and childhood stress, as the permanence of a significant person and anesthetic medication.

The importance of involving the family in the preparation of children is reinforced by encouraging families to participate in the TP sessions. It is for the truly committed professional to recognize the insecurity of parents to talk about the subject with their children and instrumentalize them with additional information when necessary, so that they can consistently help the child to face new and challenging situations. 


\section{REFERENCES}

1. Sanders J. Cuidado centrado na família da criança durante a doença e hospitalização. In: Hockenberry MJ, Wilson D, Winkelstein ML, editores. Wong Fundamentos de Enfermagem Pediátrica. 8a ed. Rio de Janeiro: Elsevier; 2011. p. 675-702.

2. Sabates AL. Reações da criança e do adolescente e de sua família. In: Almeida FA, Sabates AL, organizadoras. Enfermagem pediátrica: a criança, o adolescente e sua família no hospital. Barueri: Manole; 2008. p. 49-56.

3. Almeida FA. Psicologia do desenvolvimento: a criança. In: Farah OGD, Sá AC, organizadoras. Psicologia aplicada à enfermagem. Barueri: Manole; 2008. p. 30-59.

4. Ribeiro CA, Almeida FA, Borba RIH. A criança e o brinquedo no hospital. In: Almeida FA, Sabates AL, organizadoras. Enfermagem pediátrica: a criança, o adolescente e sua família no hospital. Barueri: Manole; 2008. p. 65-77.

5. Ribeiro CA, Borba RIH, Rezende MA. O brinquedo na assistência à saúde da criança. In: Fujimori E, Ohara CVS, organizadoras. Enfermagem e a saúde da criança na atenção básica. Barueri: Manole; 2008. p. 287-327.

6. United Nations. Resolution n.1386, of 20 November 1959. Declaration of the rights of the child. Official Records of the General Assembly [Internet]. New York; 1959 [cited 2014 Feb 5]. Available from: http://www.unicef.org/malaysia/1959-Declaration-of-the-Rights-of-the-Child.pdf

7. Brasil, Ministério da Saúde. Estatuto da criança e do adolescente [Internet]. Brasília; 2008 [citado 2014 fev. 5]. Disponível em: http://bvsms.saude.gov.br/bvs/publicacoes/estatuto_ crianca_adolescente_3ed.pdf

8. Melo LL, Valle ERM. The toy library as a possibility to unveil the life of children with cancer under outpatient treatment. Rev Esc Enferm USP [Internet]. 2010 [cited 2014 Feb 5];44(2):517-25. Available from: http://www.scielo.br/pdf/ reeusp/v44n2/en_39.pdf

9. Almeida FA. O brinquedo na pesquisa em enfermagem pediátrica [editorial]. Rev Soc Bras Enferm Pediatr. 2012;12(1):5-6.

10. Jansen MF, Santos RM, Favero L. Benefícios da utilização do brinquedo durante o cuidado de enfermagem prestado à criança hospitalizada. Rev Gaúcha Enferm [Internet]. 2010 [citado 2014 fev. 5];31(2):247-53. Disponível em: http:// www.scielo.br/pdf/rgenf/v31n2/07.pdf

11. Leite TMC, Shimo AKK. Uso do brinquedo no hospital: o que os enfermeiros brasileiros estão estudando? Rev Esc Enferm USP. 2008;42(2):389-95.
12. Cruz DSM, Virgínio NA, Maia FSB, Martins DL, Oliveira AMS. Therapeutic toy: integrative review. J Nurs UFPE on line [Internet]. 2013 [cited 2014 Jan 16];7(5):1443-8. Available from: http://www.revista.ufpe.br/revistaenfermagem/index.php/revista/article/viewFile/2833/pdf_2557

13. Conselho Federal de Enfermagem. Resolução no 295, de 24 de outubro de 2004. Dispõe sobre a utilização de técnica do brinquedo/brinquedo terapêutico pelo enfermeiro na assistência à criança hospitalizada [Internet]. Rio de Janeiro; 2004 [citado 2014 fev. 5]. Disponível em: http://novo.portalcofen.gov.br/resoluo-cofen-2952004_4331.html

14. Maia EBS, Ribeiro CA, Borba RIH. Brinquedo terapeutico: benefícios vivenciados por enfermeiras na prática assistencial à criança e família. Rev Gaúcha Enferm [Internet]. 2008 [citado 2014 fev. 5];29(1):39-46. Disponível em: http:// seer.ufrgs.br/RevistaGauchadeEnfermagem/article/viewFile/5262/2996

15. Francischinelli AGB, Almeida FA, Fernandes DMSO. Routine use of therapeutic play in the care of hospitalized children: nurses' perceptions. Acta Paul Enferm [Internet]. 2012 [cited 2014 Feb 5];(1):18-23. Available from: http://www.scielo. br/pdf/ape/v25n1/en_v25n1a04.pdf

16. Maia EBS, Ribeiro CA, Borba RIH. Understanding nurses' awareness as to the se of therapeutic play in child care. Rev Esc Enferm USP [Internet]. 2011 [cited 2014 Feb 5]; 45(4):839-46. Available from: http://www.scielo.br/pdf/ reeusp/v45n4/en_v45n4a07.pdf

17. Almeida FA. Em busca da confiança necessária para viver criativamente pelo brincar: a criança diante da cirurgia cardíaca [tese]. São Paulo: Instituto de Psicologia, Universidade de São Paulo; 2003.

18. Winnicott DW. O brincar e a realidade. Rio de Janeiro: Imago; 1975.

19. Almeida FA, Bomtempo E. O brinquedo terapêutico como apoio emocional à cirurgia cardíaca em crianças pequenas. Bol Acad Paul Psicol. 2004;24(1/4):35-40.

20. Artilheiro APS, Almeida FA, Chacon JMF. Use of therapeutic play in preparing preschool children for outpatient chemotherapy. Acta Paul Enferm [Internet] 2011 [cited 2014 Feb 5];24(5):611-6. Available from: http://www.scielo.br/pdf/ ape/v24n5/03v24n5.pdf 
21. Fontes CMB, Mondini CCSD, Moraes MCAF, Bachega MI, Maximino NP. Utilização do brinquedo terapêutico na assistência à criança hospitalizada. Rev Bras Educ Espec [Internet]. 2010 [citado 2014 fev. 5];16(1):95-106. Disponível em: http://www.scielo.br/pdf/rbee/v16n1/08.pdf

22. Kiche MT, Almeida FA. Brinquedo terapêutico: estratégia de alívio da dor e tensão durante o curativo cirúrgico em crianças. Acta Paul Enferm [Internet]. 2009 [citado 2014 fev. 5];22(2):125-30. Disponível em: http://www.scielo.br/pdf/ ape/v22n2/a02v22n2.pdf

23. Belzarena SDG. Pré-anestesia com midazolan em cirurgia pediátrica ambulatorial. Rev Bras Anestesiol. 1989;39(4):277-80.

24. Campos MC, Rodrigues KCS, Pinto MCM. Evaluation of the behavior of the preschool one just admitted in the unit of pediatrics and the use of the therapeutic toy. Einstein (São Paulo) [Internet]. 2010 [cited 2014 Fev 5];8(1 Pt1):10-7. Available from: http://apps.einstein.br/revista/arquivos/ PDF/1462-Einsteinv8n1p10-17.pdf
25. Tondatti PC, Correa I. Use of music and play in pediatric nursing care in the hospital context. Invest Educ Enferm [Internet]. 2012 [cited 2014 Fev 5];30(3):362-70. Available from: http://www.scielo.org.co/pdf/iee/v30n3/v30n3a09.pdf

26. Souza LPS, Silva CC, Brito JCA, Santos APO, Fonseca ADG, Lopes JR, et al. O brinquedo terapêutico e o lúdico na visão da equipe de enfermagem. J Health Sci Inst [Internet]. 2012 [citado 2014 fev. 5];2012;30(4):354-8. Disponível em: http://www.unip.br/comunicacao/publicacoes/ics/edicoes/2012/04_out-dez/V30_n4_2012_p354a358.pdf

27. Conceição CM, Ribeiro CA, Borba RIH, Ohara CVS, Andrade PR. Brinquedo terapêutico no prepare da criança para punção venosa ambulatorial: percepção dos pais e acompanhantes. Esc Anna Nery Rev Enferm [Internet]. 2011[citado 2014 fev. 5]; 15(2):346-353. Disponível em: http://www.redalyc.org/pdf/1277/127719099018.pdf 